\title{
EXTRACTION OF RESIDUE OIL FROM PALM OIL MILL EFFLUENT (POME) USING ORGANIC SOLVENT
}

\author{
A.L. Ahmad*, K. Sithamparam, M.M.D. Zulkali and S. Ismail \\ School of Chemical Engineering, Universiti Sains Malaysia \\ Engineering Campus, Seri Ampangan, \\ 14300 Nibong Tebal, Penang, Malaysia
}

Received 24 February 2003, Accepted 18 September 2003

\begin{abstract}
Palm oil industry in Malaysia has grown to become an important agriculture based industry and it is accounted for about $52 \%$ of the world palm oil output, which generated RM 13 billions export earning for the country. With increased cultivation and production of palm oil in the region, the disposal of the processed waste will become a major problem if it is not being treated properly. Palm oil mill effluent (POME) is extremely polluting with its high organic content. Oil and grease content in POME is $4,000 \mathrm{mg} / \mathrm{L}$ which is relatively high compared to the allowable limit by the Malaysian Department of Environment of only $50 \mathrm{mg} / \mathrm{L}$. This paper describes the research results in removing oil and grease content for the POME using solvent extraction method. Six different organic solvents; n-hexane, n-heptane, benzene, petroleum ether, pentane and petroleum benzene were used. For every solvent the effect of solvent ratio, mixing time, mixing speed and $\mathrm{pH}$ were analyzed to determine the optimum condition for maximum extraction of oil. Results showed that $n$-hexane give the best performance in extracting oil from POME with solvent to POME ratio of 6:10. It was estimated about 0.54 grams of oil and grease per liter of POME can be extracted at optimum conditions; mixing speed of $200 \mathrm{rpm}$, 20 minutes mixing time and at $\mathrm{pH} 9$.
\end{abstract}

Keywords : Solvent extraction, organic solvent, POME, residue oil.

\section{INTRODUCTION}

Currently there are about 3.0 million hectares of land under palm oil cultivation and 300 palm oil mills to process the fresh fruit bunches (FFB). In 1998, Malaysia produced 8.33 million tons of crude palm oil (CPO) and 1.1 million tons of crude palm kernel oil (CPKO). Palm oil and its product have becomes the country's major export revenue earner valued at about RM 22.6 billion. This accounted for about 60.5 percent of the export earnings from commodity and commodity based products in 1998 and has helped to a large extent reduced the impact of the economic crisis faced by the country.

*Corresponding author-email: chlatif@eng.usm.my 
Besides crude palm oil and palm kernel, palm oil mills also generate large amounts of solid and liquid by-products; empty fruit bunches (EFB), fibre, shell and palm oil mill effluent (POME) as shown in Table $1^{1}$.

Table 1 : Estimated by-products generated by palm oil mills in $1998 .^{1}$

\begin{tabular}{lccc}
\hline \multicolumn{1}{c}{ By-product } & Million tons & $\begin{array}{c}\text { Moisture content } \\
(\%)\end{array}$ & $\begin{array}{c}\text { Heat value } \\
(\text { dry basis })(\mathrm{kcal} / \mathrm{kg})\end{array}$ \\
\hline Fibre & 5.8 & 42 & 4420 \\
Shell & 3.7 & 7 & 4950 \\
Empty fruit bunches & 9.6 & 65 & 3700 \\
Palm oil mill effluent & 21.0 & 95 & - \\
\hline
\end{tabular}

POME is a colloidal suspension of $95-96 \%$ water, $0.6-0.7 \%$ oil and $4-5 \%$ total solids including $2-4 \%$ suspended solids originated from the mixture of a sterilizer condensate, separator sludge and hydrocyclone wastewater ${ }^{1}$. The quantity of POME produced is about $60 \%$ for every tonne of fresh fruit bunches (FFB) processed. Thus, for a mill processing an average of 30 tonnes FFB/hr about 18-19.5 tonnes effluent/hr will be generated ${ }^{2}$. With over 300 palm oil mills in Malaysia, their generation of large volumes of effluent could give significant impact to the environment since the characteristics of POME are extremely polluting with its high content of Biochemical Oxygen Demand (BOD), Chemical Oxygen Demand (COD), suspended solids and oil and grease which will deteriorate the quality of receiving waters. The characteristic of raw POME is shown in Table $2^{1}$.

Table 2 : Characteristics of palm oil mill effluent. ${ }^{1}$

\begin{tabular}{lc}
\hline Parameter /Element & Concentration* \\
\hline $\mathrm{pH}$ & 4.7 \\
Oil and grease & 4000 \\
Biochemical oxygen demand (BOD) & 25000 \\
Chemical oxygen demand (COD) & 50000 \\
Total solids & 40500 \\
Suspended solids & 18000 \\
Total volatile solids & 34000 \\
Ammoniacal nitrogen & 35 \\
Total nitrogen & 750 \\
Phosphorus & 180 \\
Potassium & 2270 \\
Magnesium & 615 \\
Calcium & 439 \\
Boron & 7.6 \\
Iron & 46.5 \\
Manganese & 2.0 \\
Copper & 0.89 \\
Zinc & 2.3 \\
\hline
\end{tabular}

*All parameters in $\mathrm{mg} / \mathrm{L}$ except $\mathrm{pH}$. 
Looking at the seriousness of environmental impact by palm oil industry, the government has enacted the Malaysian Environmental Quality Act, 1974 and Environmental Quality (Prescribed Premises)(Crude Palm Oil) Regulations 1977. The Department of Environment (DOE) has set the discharge standards for POME as shown in Table $3^{1}$. Therefore, the palm oil industry faces the challenge of balancing the environmental protection, its economic viability and sustainable development.

Table 3 : Parameter limits for watercourse discharge of POME. ${ }^{1}$

\begin{tabular}{lc}
\hline *Biochemical oxygen demand $(\mathrm{BOD})(\mathrm{mg} / \mathrm{L})$ & 100 \\
Suspended solids $(\mathrm{mg} / \mathrm{L})$ & 400 \\
Oil and grease $(\mathrm{mg} / \mathrm{L})$ & 50 \\
Ammoniacal nitrogen $(\mathrm{mg} / \mathrm{L})$ & 150 \\
Total nitrogen $(\mathrm{mg} / \mathrm{L})$ & 200 \\
PH & $5-9$ \\
\hline
\end{tabular}

*BOD-sample incubated for 3 days at $30^{\circ} \mathrm{C}$.

Several innovative treatment technologies have been developed and applied by palm oil mills to treat POME and conventional biological treatments of anaerobic or facultative digestion are the most commonly used ${ }^{3,4}$. However, this biological treatment system needs proper maintenance and monitoring as the processes rely solely on microorganisms to break down the pollutants. The microorganisms are very sensitive to changes in the environment and thus great care has to be taken to ensure that a conducive environment is maintained for the microorganisms to thrive in. Besides, it also generates vast amount of biogas. This biogas contains of methane, carbon dioxide and trace amount of hydrogen sulphide, which are corrosive and odorous.

Besides the biological treatment, evaporation process has been suggested to treat POME. By using POME containing 3-4 \% total solids as feed, about $85 \%$ of the water in the POME can be recovered as distillate. Unfortunately energy requirement is a major constrain in this process. It was found that one $\mathrm{kg}$ of steam is required to evaporate one $\mathrm{kg}$ of water content in POME${ }^{1}$.

Another physical method of treatment, air-floatation systems was tested on a pilot plant scale. In this system, tiny, bubbles of air or oxygen are released in the effluent. In rising through the surface of the effluent, this bubbles carry suspended solids to the surface where they are easily removed. However it was found to be very inefficient and unreliable 5 .

Full scale tests were carried out using centrifuge process. The suspended solids are separated from the liquid or concentrated by means of centrifuges but the system found to be unsatisfactory due to high wear rates and erratic operation ${ }^{5}$.

Although several systems of treatment have been introduced and successfully applied, there are still some mills that fail to comply with the regulatory standard set by the Malaysian Department of Environment (DOE). Solvent Extraction method is the most powerful separation and purification tool in the process industries. It is used commercially in hydrometallurgy (including nuclear industry) and widely within the chemical industry including organic chemical, petrochemical and pharmaceuticals. 
Solvent extraction has assumed importance in virtually all vegetable oil recovery plant. It recovers up to 98 percent of the cotton seed oil. The soybean, which has low oil content, but whose physical structure is particularly suited to solvent extraction has been responsible for this development and solvent hexane is used for this purpose ${ }^{6}$. While in pharmaceutical industry, solvent extraction method is extensively used for purification and concentration of penicillin by utilizing n-butyl acetate or amyl acetate as solvent ${ }^{7}$

The objective of the current research is to extract the residue oil content in POME using solvent extraction method. Different organic solvents used were n-hexane, benzene, petroleum benzene, petroleum ether, pentene and n-heptane. The effect of solvent ratio to POME, mixing speed, mixing time and $\mathrm{pH}$ were studied to get the optimum experiment parameter in extracting as maximum as possible the residue oil in POME using these organic solvents.

\section{SOLVENT EXTRACTION}

Liquid/liquid extraction, or solvent extraction ${ }^{8}$, is the separation of constituents from a liquid solution by contact with another liquid in which the constituents are more soluble. The second liquid, or extracting solution, is usually immiscible in water at the extraction conditions. The constituents are transferred from one liquid to the other but are unchanged chemically. The extraction solution is selected in such a way that it can be reused and easily separated from the bulk wastewater stream.

The solvent extraction process consists of four basic components 9 .

- Contact between wastewater and solvent;

- Separation of extracted wastewater and solvent;

- Treatment of solvent to remove extracted constituents; and

- Treatment of wastewater to remove residual solvent.

Solvent extraction is used in numerous chemical industries to produce pure chemical compounds, ranging from pharmaceutical and biomedical to heavy organics and metals, in analytical chemistry, in environmental waste purification, as well as in research ${ }^{7}$.

The principle is illustrated in a separation funnel that contains two layers of liquids. One that is generally water $\left(\mathrm{S}_{\mathrm{aq}}\right)$ and the other, generally, an organic solvent $\left(\mathrm{S}_{\mathrm{org}}\right)$. Normally the organic solvent has a lower density than water, but the opposite situation is also possible. A solute A, which is initially is dissolved in only one of the two liquids, eventually distributes between the two phases. When this distribution reaches equilibrium, the solute is at concentration $[\mathrm{A}]_{\mathrm{aq}}$ in the aqueous layer and at concentration $[\mathrm{A}]_{\text {org }}$ in the organic layer. The distribution ratio of the solute, $\mathrm{D}$ is defined as ${ }^{7}$

$$
\mathrm{D}=[\mathrm{A}]_{\text {org }} /[\mathrm{A}]_{\mathrm{aq}}
$$

In other word, D can be defined as "the total analytical concentration of the substance in the organic phase to its total analytical concentration in the aqueous phase, usually measured at equilibrium" 10 , irrespective of whether the organic phase is the lighter or the heavier one. 
Process efficiency will depend on the equilibrium distribution of the constituents between the wastewater and the extracting solvent and the kinetics of mass transfer between the two liquid phases. To increase efficiency, the solvent-to-waste ratio can be increased, or multiple extraction stages can be employed.

In metallurgy process, solvent extraction of a metal is heavily dependent on the concentration of the extraction in organic phase and on the $\mathrm{pH}$ of the aqueous phase. The extraction coefficient, $\mathrm{E}$, is a measure of how well a solvent will extract a metal, that is, a measure of the overall driving force of the solvent extraction system, and thus concentration dependent. As defined, $\mathrm{E}$ is a number, has no units, and is not a constant. The value of $\mathrm{E}$ depends on many factors, such as the phase (aqueous/organic) ratio, extractant concentration, temperature, $\mathrm{pH}$, metal complexation in the aqueous and organic phases, and metal concentration in the aqueous phase ${ }^{11}$. Solvent selection is frequently a compromise among all the properties listed above. However, initial consideration is usually given first to selectivity and environmental concerns, and second to capacity.

\section{MATERIALS AND EXPERIMENTAL PROCEDURE}

\subsection{Materials}

Six technical grade solvents n-hexane, n-heptane, benzene, petroleum ether, pentane and petroleum benzene were employed in the extraction study. All the solvents were bought from R\&M Chemicals, Essex, United Kingdom. Fresh POME samples were collected from a palm oil mill, Felcra Nasaruddin Palm Oil Mill, Perak, Malaysia. The fresh POME with temperature approximately $90^{\circ} \mathrm{C}$ and $\mathrm{pH} 4-5$ was stored in refrigerator in order to cool down before it is being used for experimental testing.

\subsection{Experiment}

Extraction of oil with different ratio of solvent to palm oil mill effluent has been done at room temperature. $300 \mathrm{ml}$ sample of POME was mixed with $60 \mathrm{ml}$ of solvent and the volume of solvent was increased by $60 \mathrm{ml}$ for every experiment until the ratio of solvent to POME reaches 10:10. The mixture was covered with a thin layer of aluminium wool to prevent any evaporation of the solvent from stirring/mixing process with selected speed and time. Later the contents were transferred to the separation funnels. The mixtures were left for 5 minutes to allow complete two layers separation. The contaminated solvent and the POME were then collected into different beakers.

\subsection{Determination of oil and grease content}

The extracted POME was then transferred to another separating funnel, its container was rinse with $30 \mathrm{ml}$ of petroleum ether and later added to separating funnel. This mixture was shaken vigorously before letting the layer separated for another 5 minutes. Solvent layer was drained 
through a funnel containing a filter paper and $2 \mathrm{~g}$ anhydrous sodium sulphate (function to absorb water) into a clean conical flask. The extraction was repeated with another two portion of 30 $\mathrm{ml}$ petroleum ether. The entire sample container was rinsed each time with petroleum ether before adding it to the separation funnel. The solvent was distilled off using rotary evaporator up to its boiling point, the boiling point of the solvent is shown in Table $4^{12}$. The drying was completed in an oven at $103^{\circ} \mathrm{C}$ for 5 to 10 minutes. The flask was cooled in a desiccator for 30 minutes and then weighed. The drying and cooling steps were repeated until the weight becomes constant. The measured weight is taken as oil and grease content value. Figure 1 illustrates the experimental procedure for solvent extraction of POME.

Similar procedure was carried out for other solvent while several experimental parameters such as solvent-POME ratio, mixing rate, mixing time and $\mathrm{pH}$ are varied to determined the optimum condition. All experiments were repeated for 5 times and the results were reproducible within $\pm 10 \%$.

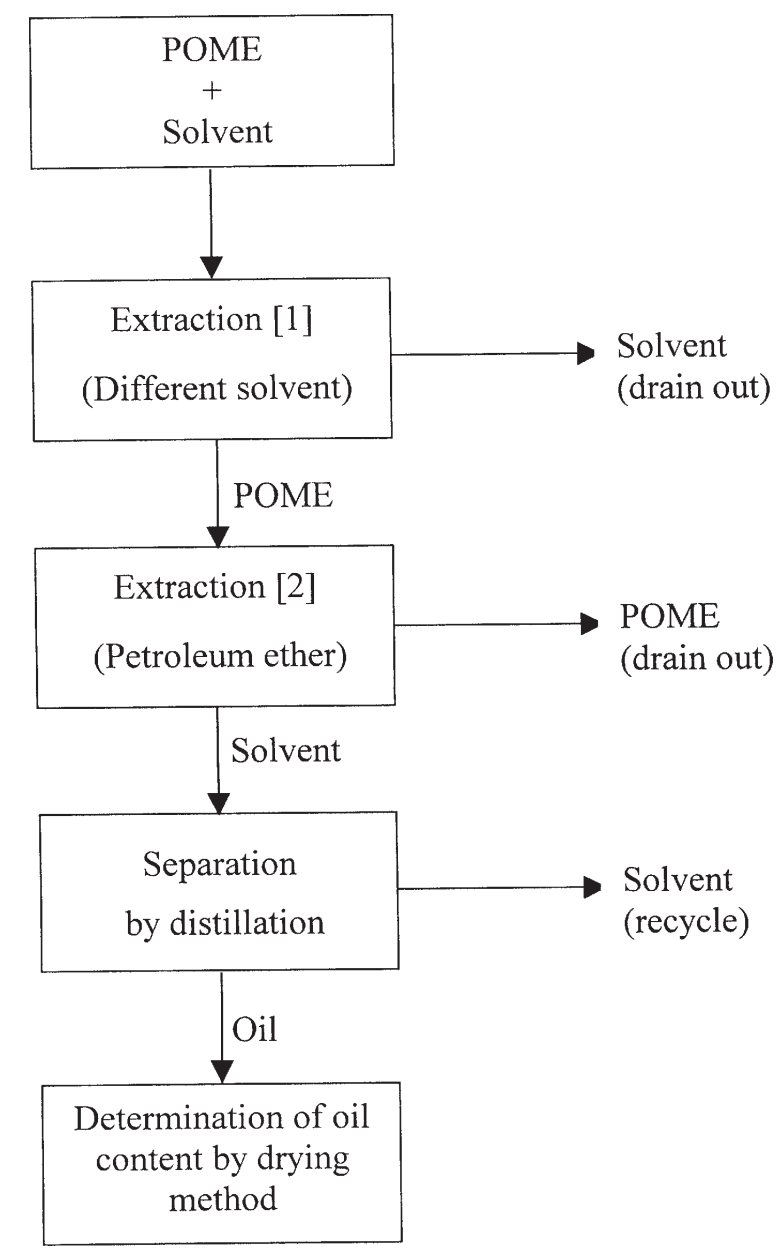

Figure 1 : Block diagram of the experimental procedure 
Table 4 : Boiling point of Solvent. ${ }^{12}$

\begin{tabular}{lc}
\hline Solvent & Boiling Point $\left({ }^{\circ} \mathrm{C}\right)$ \\
\hline n-hexane & 69 \\
n-heptane & 98.4 \\
benzene & 80.1 \\
petroleum ether & 60 \\
pentane & 36.3 \\
\hline
\end{tabular}

\section{RESULTS AND DISCUSSION}

Results are presented on the effect of all the experimental parameter against the amount of residue oil extracted. Figures 2 to 5 show the average amount from five repeating experiment for different study effects. In each figure, the graph was numbered by 1, 2, 3, 4, 5 and 6 representing different solvents used which are n-hexane, benzene, petroleum benzene, petroleum ether, pentane and n-heptane respectively.

\subsection{Effect of solvent ratio}

Figure 2 shows the effect of solvent ratio to POME on the amount of oil extracted. This figure clearly shows that as the amount of solvent increases, the amount of oil extracted is also increase. However after a certain amount of solvent (at ratio 6:10) the increment of oil extracted is very little and almost constant. This phenomenon shows that at solvent ratio 6:10, the extraction process has reached the saturation value, which indicates that the stability of emulsion has been formed and will reduce the ability of solvent to extract oil ${ }^{13}$. Hence the solvent ratio to POME at 6:10 is the optimum solvent ratio value for the current extraction process.

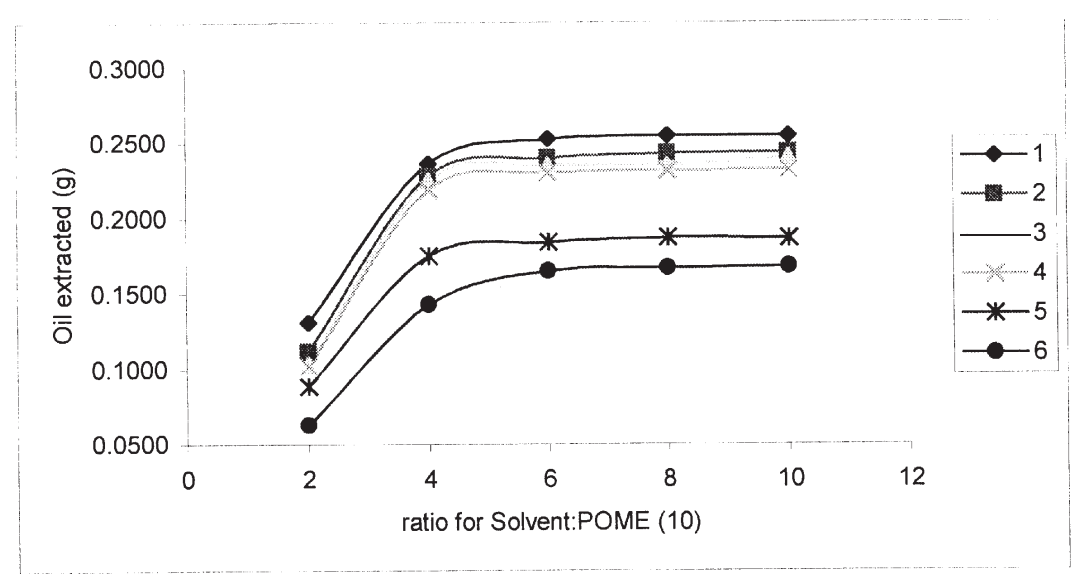

Figure 2 : The effect of solvent-POME ratio on extraction of oil. 


\subsection{Effect of mixing speed}

Mixing usually produces and maintains a uniform and homogeneous solution. On the other hand, mixing two immiscible solutions often initiates reaction by bringing substances into contact and while agitated a system is created having dispersed liquid droplets in continuous liquid phase. Thus it creates condition favorable for mass transfer. As the speed of mixing increases, the chances for the molecules to meet one another is higher and this makes the rate of reaction or extraction to increase. Figure 3 shows the effect of mixing speed on the extraction of oil, which it implies that the rate of mass transfer increases with speed. Therefore increasing the mixing speed will increase the value of oil extracted from POME. The maximum extraction occurs at the speed of $200 \mathrm{rpm}$ for all the solvents. However, once the mixing speed is greater than $200 \mathrm{rpm}$, the oil extracted becomes almost constant. This occurrence suggested almost all fatty acids already extracted from POME. Increasing the speed after this stage will not result any further extraction of oil with mechanical energy finally dissipated as heat and it evaporates the solvent.

Mixing provide one or more additional degrees of freedom which may be adjusted to enhance contactor performance. The mixing frequency may be used to adjust the average droplet size ${ }^{14}$.

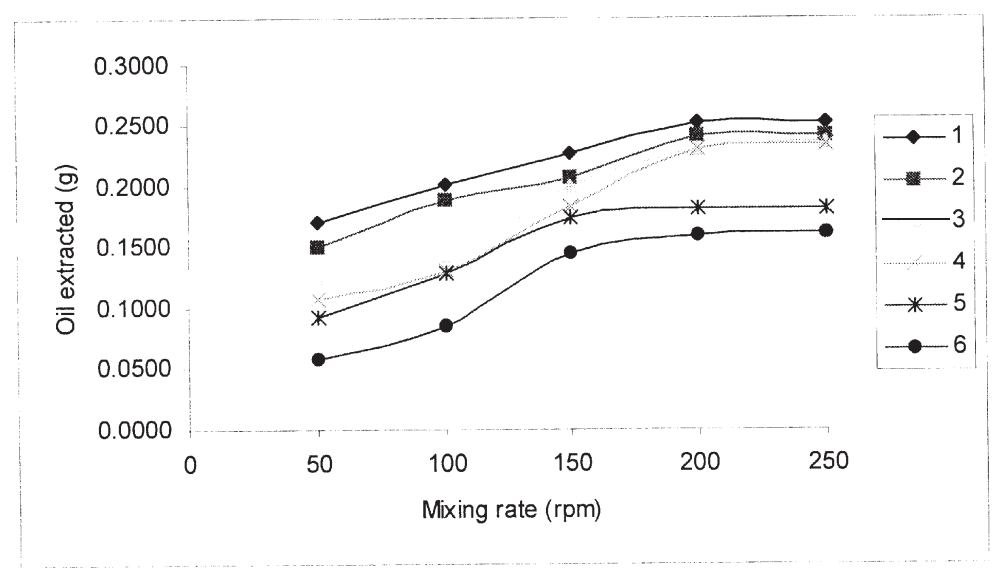

Figure 3 : The effect of mixing rate on extraction of oil.

\subsection{Effect of mixing time}

Figure 4 shows the effect of mixing time on average value of oil extracted. Result on mixing time gives almost the same trend as the mixing speed. The rapid oil extraction occurred until it reached a constant value after 20 minutes. This is because, increasing the mixing time of more than 20 minutes may not result further extraction of oil once equilibrium has been attained. Besides, the distribution of oil size molecules cannot be changed after reaching the equilibrium ${ }^{13}$. Therefore, it is obviously illustrated from the figure that the equilibrium can be achieved in the period of 20 minutes. 


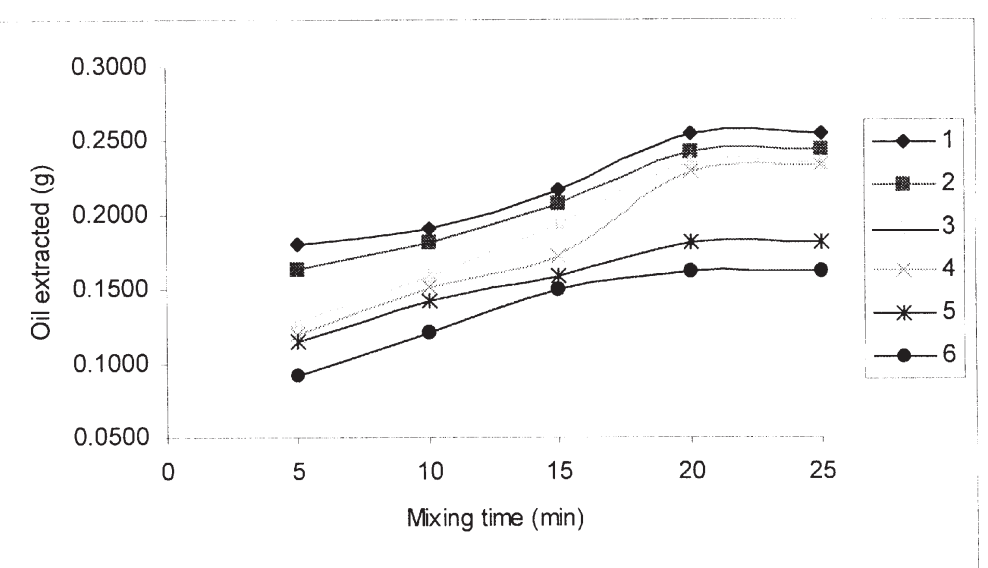

Figure 4: The effect of mixing time on extraction of oil.

\subsection{Effect of $\mathrm{pH}$}

Figure 5 shows the effect of $\mathrm{pH}$ on average value of oil extracted. It shows that for all the solvent used, the amount of oil extracted were low at $\mathrm{pH} \leq 7$ but reach maximum at $\mathrm{pH} 9$. However this phenomenon is not illustrating that the residual oil extraction is effective at $\mathrm{pH}$ 9. In this study, $\mathrm{NaOH}$ is being added to POME to increase the $\mathrm{pH}$. This activity will lead to the saponification process where the residual oil will react or undergo hydrolysis with $\mathrm{NaOH}$ to produce glycerol and a fatty acid salt called soap ${ }^{15}$. The soap is more soluble in water (POME) rather than the organic solvent. Therefore, while determining the oil concentration in treated sample using petroleum ether, the weight of oil found to be less in the solvent at $\mathrm{pH} 9$ since the oil was hydrolyzed inside the POME. This lead to higher value of oil extracted at $\mathrm{pH} 9$. Thus utilizing the original $\mathrm{pH}$ of POME for residual oil extraction is preferred rather than adjusting the $\mathrm{pH}$ using strong acid or alkali to avoid hydrolysis reaction.

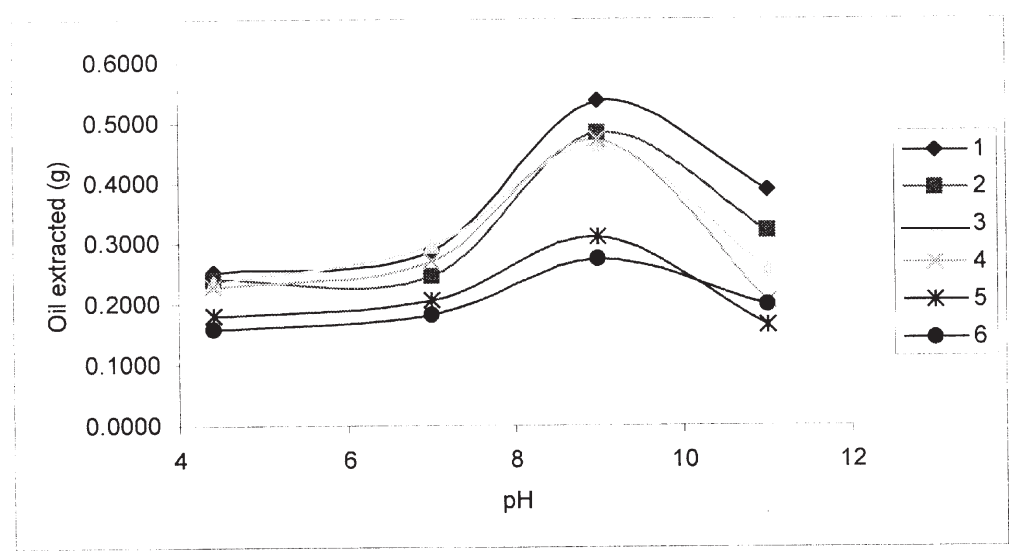

Figure 5 : The effect of $p H$ on extraction of oil. 


\section{CONCLUSION}

Solvent extraction has proved that it can be one of the methodologies in reducing the content of oil and grease in palm oil mill effluent. This was reflected by the above results obtained after several batches of experiments. The results showed that $n$-hexane is the best organic solvent to extract the oil and grease content from POME following by benzene, petroleum benzene, petroleum ether, pentane and n-heptane. By using n-hexane as the solvent, it is estimated that about 0.54 grams of oil and grease per liter of POME can be extracted with optimum conditions applied. The optimum solvent to POME ratio is 6:10, optimum mixing speed is $200 \mathrm{rpm}$, optimum mixing time is 20 minutes and optimum $\mathrm{pH}$ is 9 .

\section{ACKNOWLEDGEMENT}

The authors are grateful to acknowledge Yayasan Felda that has fully supported this research.

\section{REFERENCES}

1. $\quad$ Ma, A N.(2000), Palm Oil Developments, 2000, no. 30, pp. 1-10.

2. Rusnani, A M, Ma, A N and Hisham, E. (1999), PORIM Bulletin,no. 39, pp. 25-31.

3. Hanif, J.(1994), Natural rubber serum quality. Seminar Hari Alam Sekitar Pengurusan Effluent Kelapa Sawit dan Getah, Melaka (21 December).

4. Quah, S K, Lim, K H, Gillies, D., Wood, B J and Kanagaratnam, J. (1982),Sime Darby POME treatment and land application systems. Proceedings of Regional Workshop On Palm Oil Mill Technology and Effluent Treatment, PORIM, Kuala Lumpur, pp. 193-200.

5. Mahabot, S and Harun, A.R. (1990), Effluent Treatment System for FELDA's Palm Oil Mill, Bahagian Khidmat Teknik, Perbadanan Kilang Felda,Kuala Lumpur.

6. George, T. A. (1984), Shreve's Chemical Process Industries, Fifth Edition,Mc.Graw Hill, Singapore, pp. 508-528.

7. Rydberg, J.(1992),Introduction to Solvent Extraction, Marcel Dekker, New York.

8. Freeman, H M. (1989), Standard Handbook of Hazardous Waste Treatment and Disposal, McGraw-Hill, New York.

9. Belhateche, D H. (1995), Choose appropriate wastewater treatment technologies. Chemical Engineering Progress, pp. 32-51.

10. Freiser, H and Nancollas, G H. (1987), Compendium of Analytical Nomenclature, Definitive Rules 1987, IUPAC, Blackwell Science Publications, Oxford.

11. Ritcey, G.M and Ashbrook, A.W. (1984), Solvent Extraction-Principles and Applications to Process Metallurgy, Part 1, Elsevier, New York, pp. 40-86.

12. David, R.L. (1989),CRC Handbook of Chemistry and Physics, CRC Press Boca Raton, New York.

13. Harnby, N., Edwards, M.F. and Nienow, A.W. (1994), Mixing in the process Industries, $2^{\text {nd }}$ ed. Oxford: Butterworth Heinemann.

14. Ronald W. R. (1987), Handbook of Separation Process Technology, John Wiley \& Sons, USA, pp. 405-466.

15. Xinia, E.F., Nathan, W.S. and Bruce, A.W.(2000), Journal of Food Comp. and Analysis, vol.13, pp. 179-187. 